\title{
A Vicious Circle: The Interaction between Income Distribution and Household Indebtedness in the Neoliberal Era
}

\author{
Asst. Prof. Dr. İpek Tekin (Çukurova University, Turkey) \\ Assoc. Prof. Dr. Başak Gül Akar (Çukurova University, Turkey)
}

\begin{abstract}
In the neoliberal era, financialization of the economies is associated both with large-scale speculative movements in the financial sector and over-indebtedness. The fact that there were significant increases in household indebtedness in the United States before the 2008/09 global financial crisis made the growing indebtedness an outstanding issue that should be examined in terms of its supply and demand-side causes and its distributive consequences. Increasing inequality in income distribution has been an important consideration associated with the increase in household indebtedness. In a sense, the borrowing opportunities enable working households to maintain their consumption and living standards in the short term despite the stagnation in wages and thus increasing inequality, but it does not prevent them from undergoing an unsustainable debt burden. This debt burden creates a feedback effect by deepening the existing inequality. The purpose of this study is to reveal the macro and micro dynamics associated with neoliberal policies that create the supposed relationship between inequality and household indebtedness and to try to interpret the increasing household indebtedness and income inequality in Turkey in the 2000 s within this framework.
\end{abstract}

\section{Introduction}

In his famous book Fault Lines, Rajan (2010) emphasized that governments implementing populist policies prefer to increase lending opportunities through financial deregulation and access to credit, rather than using taxes and social expenditures to redistribute income. Rajan points out that low- and middle-income households have reduced their savings and increased their debts in response to apparently rising inequality in the United States starting in the early 1980s. This situation kept private consumption and employment temporarily high but led to a credit bubble of 2008 global financial crisis (Van Treeck, 2014). That has been an alternative hypothesis to the mainstream perception of the crisis which is related to irrational behaviors of economic agents.

Indeed, Figure 1 shows the share of the highest 5\% group in income distribution in the United States after 1917. Following a relatively stagnant course in the post-war $1950 \mathrm{~s}$ and $1960 \mathrm{~s}$, the income shares of the $5 \%$ began to increase significantly by the $1980 \mathrm{~s}$. While the share of this group was $21 \%$ in 1980 , it reached to $33 \%$ with an approximately 61 percent increase in 2008.
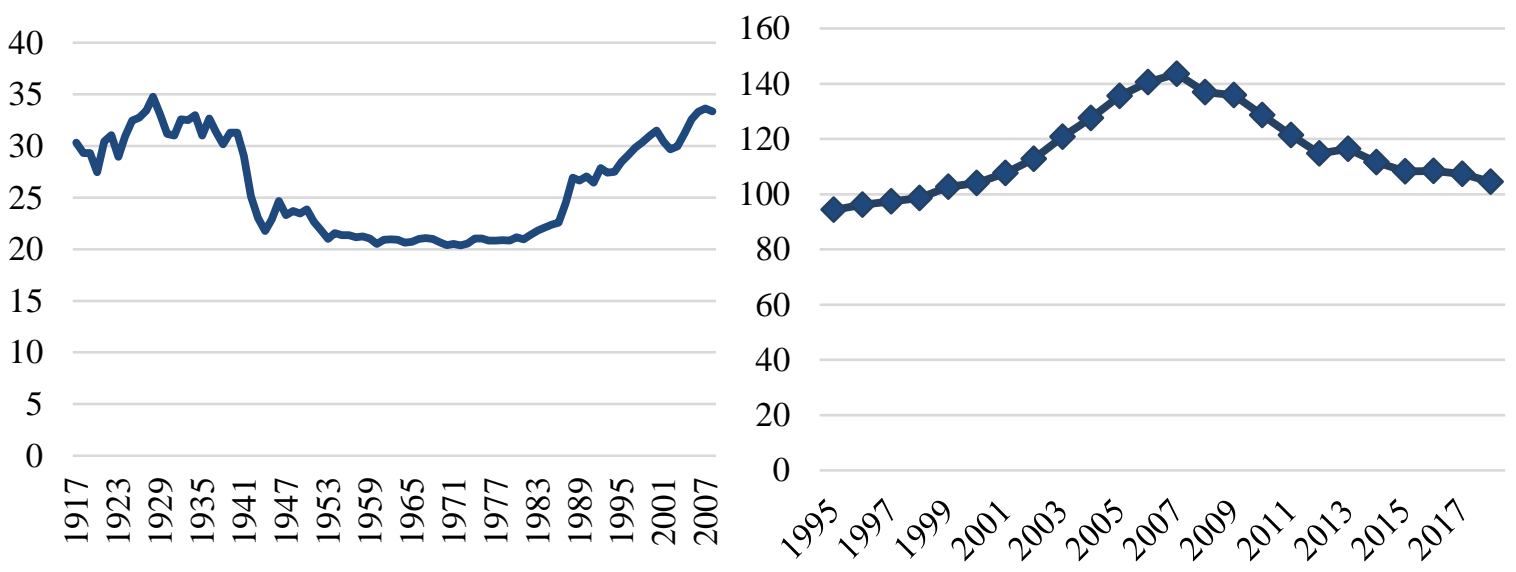

Figure 1. The share of the top 5\% in income distribution in the United States (1917-2008)

Figure 2. Household debt in the United States as a percentage of net disposable income (1995-2018)

Source: World Inequality Database (WID, 2019) Source: $O E C D, 2021$

The process likely to have prepared the conditions for the financial crisis started with the goal of making lowincome households' homeowners by increasing the number of available credits. As household debt ratio is depicted in Figure 2, household debt had been growing before the crisis. Here, all liabilities that require interest and principal payments are included in household debt as a percentage of disposable income. Figure 2 reveals the fact that household debt ratio had an increasing trend before the crisis when inequality had also been on the rise. The ratio of household debt to disposable income increased from 94 percent in 1995 to nearly 144 percent in 2007. At a glance, even though credit expansion seems like aiming to make low-income households homeowners, practically they are rather debtowners with lower shares in income distribution. Such that, referring to the WID (2019), the 
share of bottom 50 percent was 19 percent in 1980 whereas it decreased to 13 percent before the crisis and was 12 percent in 2014.

Alvarez-Cuadrado and Japaridze (2017) also state that the increase in indebtedness is concentrated in the bottom 95 percent of the income distribution, which is the segment whose access to loans was increased in the pre-crisis years. This period of credit expansion was a result of neoliberal policies, particularly financial deregulation and financialization policies implemented firstly in 1980s not only in the United States or in some developed countries but also in developing countries. However, as Önder (2009) emphasizes, since capitalism is at its most mature stage and financial fragility is at the highest level has caused the crisis to emerge in the financial sector of the United States.

Instead of trying to emphasize the widely accepted "truths" of the financial crises, and suggesting broader financial regulations to eliminate the risks and make the credit system sustainable, the purpose of this study is to examine some facts that are inherent in today's capitalism and financialization process and to understand indebtedness and inequality interaction within that debt-led financialization process, then to interpret these relations for the Turkish economy as a case study in the last decades. Particularly in recent years, the data for household indebtedness and income distribution in Turkey have pointed to a similar appearance like above.

The paper is organized as follows: In the following section, the theoretical insights and relevant literature on indebtedness and distribution dynamics of financialization are presented. In the third section, the inequalityindebtedness nexus and envisaged vicious circle are discussed for Turkey with some relevant data. In the last section, some concluding comments are offered.

\section{Household Indebtedness and Income Inequality: Theoretical Insights and Relevant Literature}

1970s are known as a stagnant phase of capitalism with low profit rates in industry and manufacturing sectors stemming from concentration of capital accumulation and decreasing productivity. In such a period, the financial sector was invaluable for capital in search of a potential source of profitability. As the starting point, it is important to consider neoliberal financial deregulation and privatization policies of 1980s in that context. Harvey (2015) claims that neoliberalism means financialization of anything and increasing control of finance in economies as well as in everyday life. Financialization in or out of the financial sector possesses the requisite sources for financial incomes or capital gains to restore profitability (Stockhammer, 2012). Similarly, debt crises of 1980s forced developing countries to implement neoliberal deregulation policies as their development recipes imposed by developed central economies and international organizations.

Since the 1980s, on the other side of the coin, labor market deregulations, stagnant wages and decreasing labor share of income have been on the stage. Because of stagnant or decreasing wages, the financial sector was also a potential source for households to generate demand required in the accumulation process and to eliminate underconsumption. More importantly, systematic transformation of the financial sector which also included lowincome households/worker households and made them actors in that process has been a radical change in the structure of societies. It is inevitable to explain the relationship between indebtedness and inequality in recent decades on the basis of neoliberal financial deregulation policies and financialization. It also requires understanding the functioning and the role of the capitalist credit and banking system in accumulation and transformation process of capitalism. While credit relations were examined within the framework of the relations between industrial capitalists and banks in the Marxist analysis, the consumer credit dimension of loans has become more of an issue in today's world. Bahçe and Köse (2016) emphasize that the expansion of the credit/borrowing cycle to include the working class is the embodiment of neoliberal policies. The possibility of borrowing enables households, in a sense, to maintain their consumption despite the stagnation in wages and increasing inequality by creating a debt welfare (this conceptualization belongs to Güngen, 2021) period.

In this regard, both supply and demand-side factors could be the determinants in indebtedness of the households as Karaçimen (2015) distinguishes. The dynamics of capital accumulation, changes in monetary and fiscal policies and the effects of these policies in the financial and real sector have a great impact on the changes in the supply of and demand for consumer loans. In this sense, besides the financial intermediation role of banks, their role in the capital accumulation process should also be taken into consideration. Willingness to borrow by the households because of rising inequality and income loss, or the role of banks in this financialization process are twodimensional (demand and supply-side) factors that function together. Indeed, Tridico (2012) supposed that deregulations and inequality in labor markets with lowering wages caused higher demand for loans on the one side; financial deregulation and loosening monetary policies caused higher credit supply on the other side of which jointly induced to that credit expansion period. Higher inequality, in other words, contributes to saving from capital of which marginal propensity to save is higher (Stockhammer, et. al, 2009), in turn increases the available funds for poorer households.

More specifically, in developed countries, since the end of the 20th century the companies scaled-up and the dependence of large-scale companies on the banks as lenders has decreased and they have turned to capital markets. 
For this reason, banks began to seek alternative sources. Loan-based securitization practices became widespread in such a process. On the other hand, with the integration of developing countries in the world markets, the decrease in international interest rates and the opportunity for capital to borrow from abroad increased. Since the 2000s, the volume of credits provided by banks to the corporate sector has shrunk; services for households have increased (Lapavitsas and dos Santos, 2008). Additionally, with the entry of foreign banks to developing countries, the loans provided to households increased. From the perspective of credit demand, on the one hand, developments in macroeconomic indicators such as inflation and decline in interest rates within the framework of price stability targets of developing countries in the 2000s led to increases in consumer loans; on the other hand, the financialization of the housing and pension sectors in developed countries on the basis of neoliberal policies, the privatization of public services in the developing countries after the 1990s, the deregulation of labor markets and the pressure on wages played an important role in the acceleration of the financialization process and the increase in borrowing (Karaçimen, 2015). Additionally, by analyzing the causes of rising household debt, Barba and Pivetti (2009) suggest that rising household debt in the United States should be considered as a response to rising income inequality. In other words, stagnant or declining wage and salaries are the causes of rising household debt. Even if the wages are rising, the rise is not compatible with the productivity growth.

Financial expansion supports more debt-financed expenditures of collateral-holding consumers and firms. The neoliberal growth model includes a rationale that starts with directing income from employees to high-income managers and from wages to capital. While non-financial companies contribute to financial upswing with stock buybacks and leveraged buyouts, workers continue to consume by borrowing with stagnant wages. This not only raises stock prices, but also transfers funds to households. These practices explain increased household and smallmedium enterprises borrowing, as measured by debt-to-income and debt-to-equity ratios. Increasing indebtedness, therefore, is an indicator of how the profit shifts to the unprecedentedly growing financial sector (Palley, 2009).

Considering from that aspect, debt is a potential cause of rising income inequality. Financial transactions involving workers (and other non-capitalist classes) have a distinctively exploitative dimension, stemming from the non-capitalist character of personal income cycles. Unlike loans to capitalists for production purposes, loans to households/workers support non-productive consumption and do not create surplus value to be repaid with interest. Therefore, interest payments are made over the wages of the debtors (dos Santos, 2009). This leads to the transfer of wages to the capitalists in the form of interest payments through 'financial expropriation' (Lapavitsas, 2017) which by all means worsens the distribution of income. Charpe et al. (2012) describe the economic agents in an economy as of working households, capitalist households, firms and commercial banks. Worker households borrow from capitalists and workers' debts are financed by capitalists' savings; this creates a mechanism which transfers income from workers to capitalists in the form of interest payments. So income is transferred from workers with low propensity to save to capitalists with high propensity to save. Even though debt finances consumption expenditures of the households, debt decreases the incomes of the households because of higher interest payments they are burdened with.

From a related viewpoint, Kim et al. (2019) state that a high level of indebtedness in the low and middle-income households and workers mitigates the power of workers in the bargaining process between labor and capital. Thus, wage growth decreases and leads to deterioration in the functional form of income distribution. Moreover, relatively lower wages are inevitably associated with additional borrowing and in turn higher income inequality. Slater and Spencer (2014) also make a remark that because of higher indebtedness and less bargaining power of workers, they become less able to ask for higher wages or better working conditions which most probably will be associated with deterioration in income distribution. As for the sustainability of household debt, Barba and Pivetti (2009) discuss that if interest rate is higher than the growth of household disposable income, debt-income ratio keeps rising which is only sustainable if consumption is reduced below its disposable income.

With reference to the relevant empirical literature, we conclude that findings are generally compatible with the arguments in the literature. Financialization is associated with lower labor income share (Pariboni and Tridico, 2019), higher income inequality and household debt (e.g. Dünhaupt and Hein, 2019). Some findings support the view that stagnant wages or rising income inequality/income disparity leads to credit expansion and household debt as was the case before the 2008 crisis (among others; Kumhof and Ranciere, 2011; Wisman, 2013; Klein, 2015; Perugini, et. al, 2016; Berisha, et. al, 2018). Other side of the cycle would offer a causal effect from indebtedness to inequality. A few studies support this view (e.g. Wood, 2020; De Vita and Luo, 2021).

Giraud and Grasselli (2021) by using a stock-flow consistent framework found that one of the main channels of increasing inequality is the wealth transfer as interest payments from the workers to the investors. Berisha and Meszaros (2018) analyze differently the two-way relationship between income inequality and indebtedness for the United States which reveals that increases in income inequality contributes to increases in household indebtedness which in turn increases top income share further by increasing income inequality. This result is compatible with our hypothesis of vicious circle as well as with the theoretical explanations. 


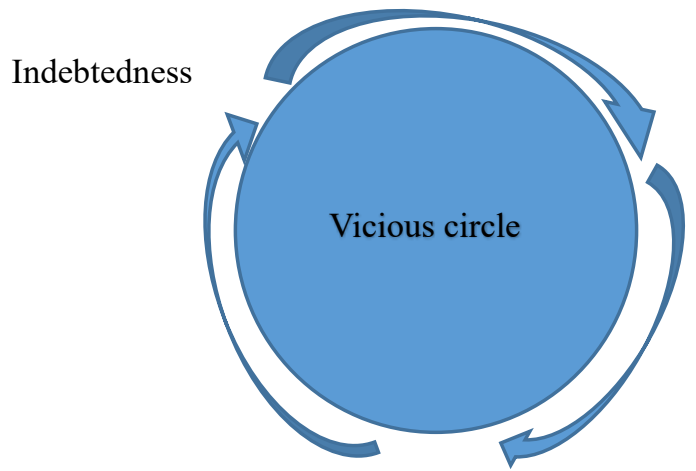

Financialization
Inequality

(Low wages and labor income share)

Figure 3. Selffeeding mechanism of financialization, indebtedness and income inequality.

Interactions between financialization, indebtedness, and income distribution explicitly create a vicious circle which inspired Figure 3 above.

In the following section, we will try to present that rising income disparities and household indebtedness are simultaneously existed and interconnected also for the Turkish economy as a peripheral economy.

\section{Wages, Household Indebtedness, and Income Distribution in Turkey}

Güngen (2021) draws a portrait of Turkish households in recent decades that are commonly included in the financial sector, using credit cards and banking accounts, calculating interest rates, and saving in financial markets.

This transformation of a "typical household" is regarded as an aspect of the global financialization process experienced after the eighties. Therefore, the dynamics behind household indebtedness is also related with the financialization of the Turkish economy as well as the other countries. Unlike early-financialized developed countries, 2000s generated the turning point for Turkey in that context: decreasing real wages, increasing indebtedness and rising inequality circle. So we tried to present the developments in these indicators particularly after the 2000s (except for some data which are also available before 2000s) compatible with what trends generally have shown already.

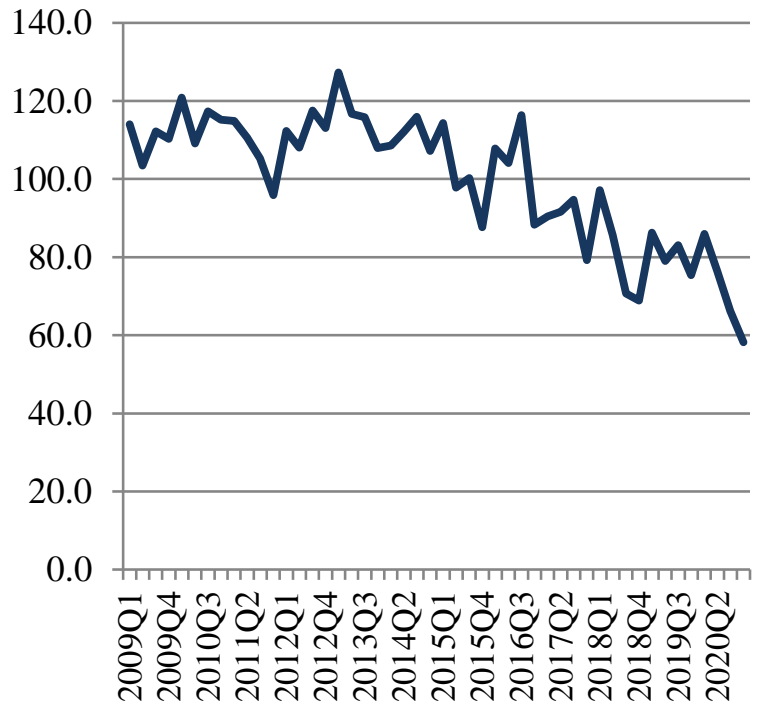

Figure 4. Real unit wage index in total industry (in terms of hours worked) $(2015=100$, quarterly), Turkey Source: Presidency of Strategy and Budget

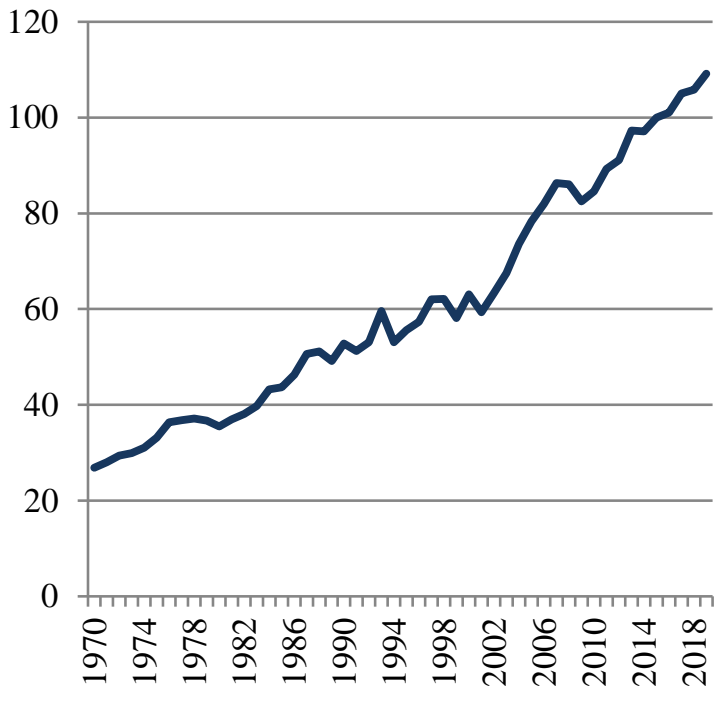

Figure 5. Labor productivity (GDP per hour worked, 2005=100, annual) Source: $O E C D$

Figure 4 shows the real unit wage index in Turkey after 2009. Accordingly, the downward trend in real wages is quite striking in terms of the position of those earn labor income/wage. On the other hand, labor productivity tends to increase except for the sudden breaks in the 1994, 2001 and 2008 crisis years as presented by Figure 4. As can be clearly seen in Figures 4 and 5, labor productivity gains have not been countered by increases in wages. Particularly after the 2001 crisis, Turkey has become integrated with the world economy through increased trade and capital flows, achieved high growth performance with low inflation and interest rates. Despite this, productivity gains after 2001 did not find a response to wage increases (Karaçimen, 2015). 
According to the model developed by Kalecki, in connection with the fact that the increase in labor productivity is not reflected in real wages, the income distribution changes in favor of those who make profits. Because the increase in productivity without an increase in real wages increases the cost margins of the companies, aggregate demand decreases and this leads to a decrease in the demand for labor. Therefore, it is necessary to avoid widening gap between productivity and real wages per worker for providing full employment and generating aggregate demand, thus not deteriorating income distribution (Lavoie, 2006).

On the other side, along with the decreasing real wages and similar to decreasing trend in global labor income share (referring to ILO-2019 report, global income share of the workers has declined from 54 percent in 2004 to 51 percent in 2017. Conversely, the share of capital income has increased from approximately 46 to 49 percent for the same period. Only the financial crisis temporarily interrupted this trend), labor income share for Turkey was 55.5 percent in 1988, it jumped to 87.4 percent in 1991 with the increase in unionization as of 1990 (while the unionization rate was 64 percent in 1988, it decreased to 51 percent in 1989; in 1990, it increased to 56 percent again). Then it started to decline in 1994 crisis and kept decreasing with the ratio of 47 percent in 2018 which is below the OECD average since the beginning of 2000s as indicated in Figure 6. Indeed, as mentioned by Berisha et al. (2018) decreasing labor share is also an explanation for increasing household indebtedness even though wages or salaries are increasing which is also related to the wages are lagging behind the productivity growth.

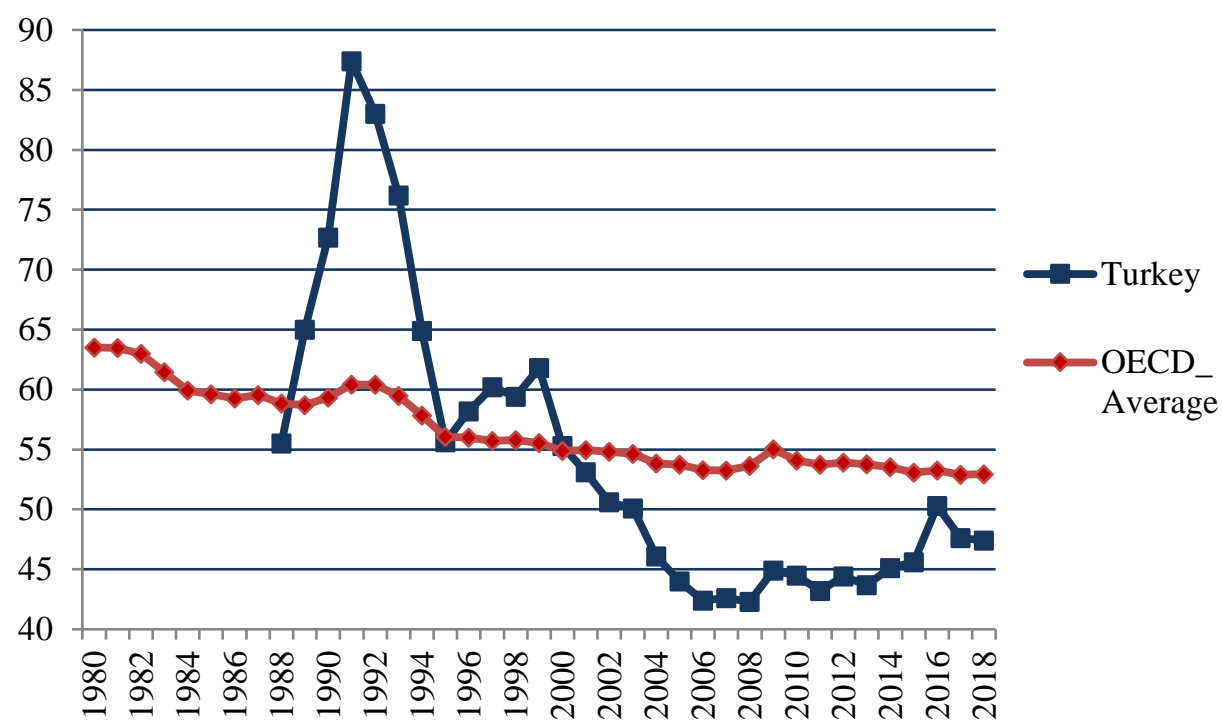

Figure 6. Labor income share in GDP (1988-2018) Source: International Labor Organization (ILO)

Elveren and Galbraith (2009) examine the wage inequality in Turkish manufacturing annually from 1980 to 2001, which also supports these trends. With the adoption of the neo-liberal policies by the $1980 \mathrm{~s}$, inequality increased significantly, especially in the 1990s. In the late 1980s, it increased in the private sector among provinces, between East and West, and among the manufacturing sub-sectors. Besides, Eksi and Kirdar (2015) examined the changes in hourly wages and annual labor income in Turkey and the inequalities created by these changes among individuals, and they found that the working hours of low-income workers in this period compared to those of high-income groups for the period 2002-2011 decreased. There is no evidence of an improvement in wage equality after 2005. The results of the study show that hourly labor income inequality among individuals decreased between 2002 and 2005. While hourly labor income inequality did not change much in the 2005-2011, there was a slight increase in hourly labor income inequality in 2007-2011 due to an improvement in favor of the upper income groups. While inequality in annual labor income decreased between 2002 and 2005, it increased after 2005 especially after 2007.

An increase in income inequality leads to both an increase in the supply of credit from those at the top of the distribution and an increase in the demand for credit from those at the bottom of the distribution. On the supply side, higher income inequality favors savings (and hence credit availability) because the rich have a greater propensity to save. On the demand side, higher inequality causes those who lower the income distribution to borrow more to sustain their consumption expenditures as their wages or salaries fall (Perugini, et. al, 2016). Empirical investigation by Perugini et al (2016) for the OECD countries revealed that the coefficient of the inequality variable is positive and significant in all estimates; this suggests that higher inequality directly leads to higher credit when its traditional determinants are controlled which is in line with what Turkish case presents in Figure 7 and 8.

As for the credit supply data in Turkey, there has been an increase in the credits provided to households and firms (private sector) by the financial sector in Turkey since the 2000s. Yeldan (2016) states that the general 
function of the Turkish banking system under financial liberalization after 1989 was to finance the public sector borrowing requirement by intermediating the sector that could not borrow directly from abroad. Before the outbreak of 2001 banking crisis, the credit channel for private sector did not work actively in Turkey.

Figure 7 shows the course of the percentage share of total domestic credits to the private sector in GDP since 2000s. Accordingly, the share of domestic credits in GDP, which was approximately 15 percent in 2001, nearly quintupled in 2020 and reached to approximately 75 percent.

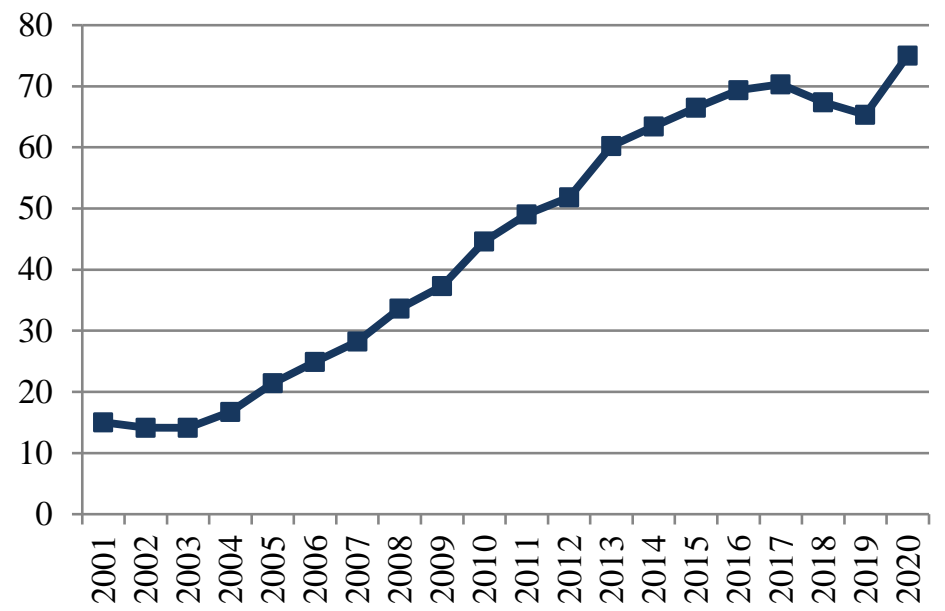

Figure 7. Domestic credit to private sector (\% of GDP) in Turkey (2001-2020) Source: World Bank World Development Indicators

Karaçimen (2015) defines the conditions that constituted the credit behavior of banks towards households. In this process, both the government's interventions in the banking sector and the changes in the financing and activities of banks and non-financial companies played an important role in the activities of banks. Soon after the crisis, as a result of the regulations in the banking sector, concentration in the sector increased and the relations of the banks with the companies were rearranged. Particularly with the implementation of contractionary monetary and fiscal policies, the profits of banks from government debt securities decreased, which had a great impact on banks' turning to households as an alternative field of activity.

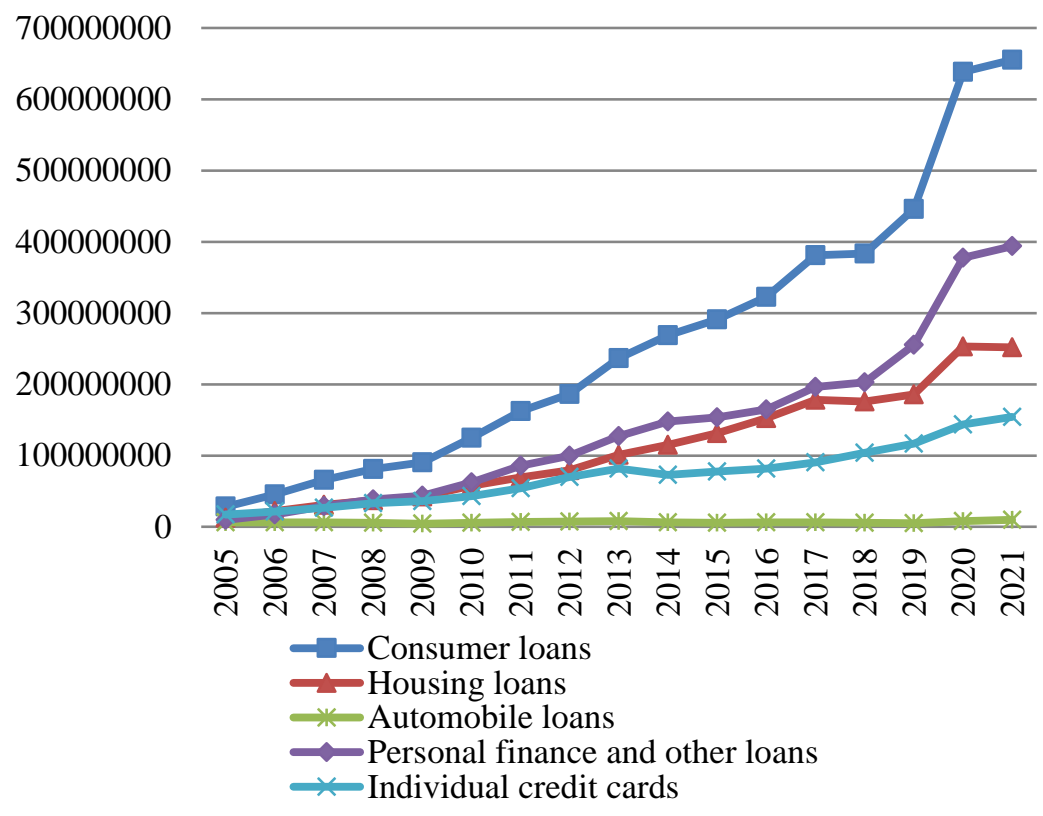

Figure 8. Consumer loans by deposit money banks (2005-2021, annual, thousand TL) Source: CBRT-EVDS Data Central Note: Only first 4 months are available for 2021.

Figure 8 shows that all types of loans (consumer, housing, automobile, personal finance, or individual credit cards), particularly consumer loans, provided by deposit banks to the households in Turkey have been increasing since 2005. 
The increased performance of the Turkish economy after the 2001 crisis mentioned above seems to have come at the expense of stagnation in wages. As a matter of fact, Filiztekin and Çelik (2010) attempted to understand the structure of income inequality in Turkey from a regional perspective, it was concluded that economic development or growth did not succeed in reducing income inequality in Turkey. In the post-2001 process, factors such as the increase in imports, the proliferation of shopping malls, households being familiar with new brands, import of consumption preferences as well as trade and capital flows, inevitably accompanied an increase in household borrowing demand, incompatible with wages. Figure 9 shows the increase in household debt and interest payments in 2000s. Even though the available data for the share of household debt in disposable income and interest payments are limited, increasing trend is clearly seen below.

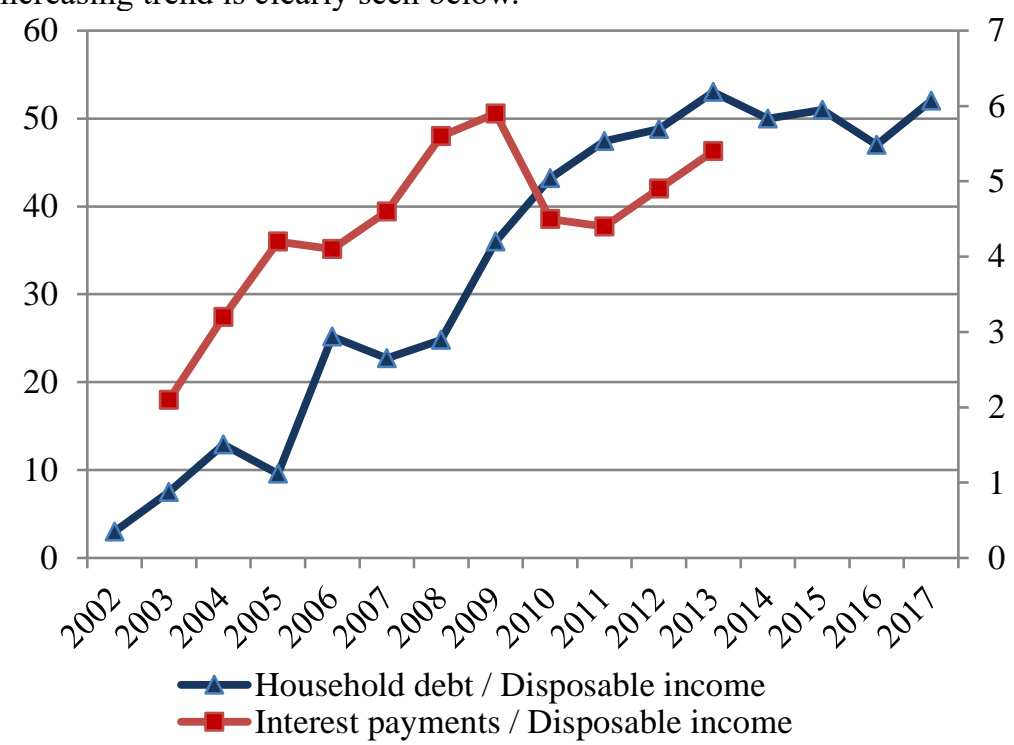

Figure 9. Household debt and interest payments of the households in Turkey (2002-2020 \& 2003-2013) (Household debt on the left axis) Source: CBRT Financial Stability Reports

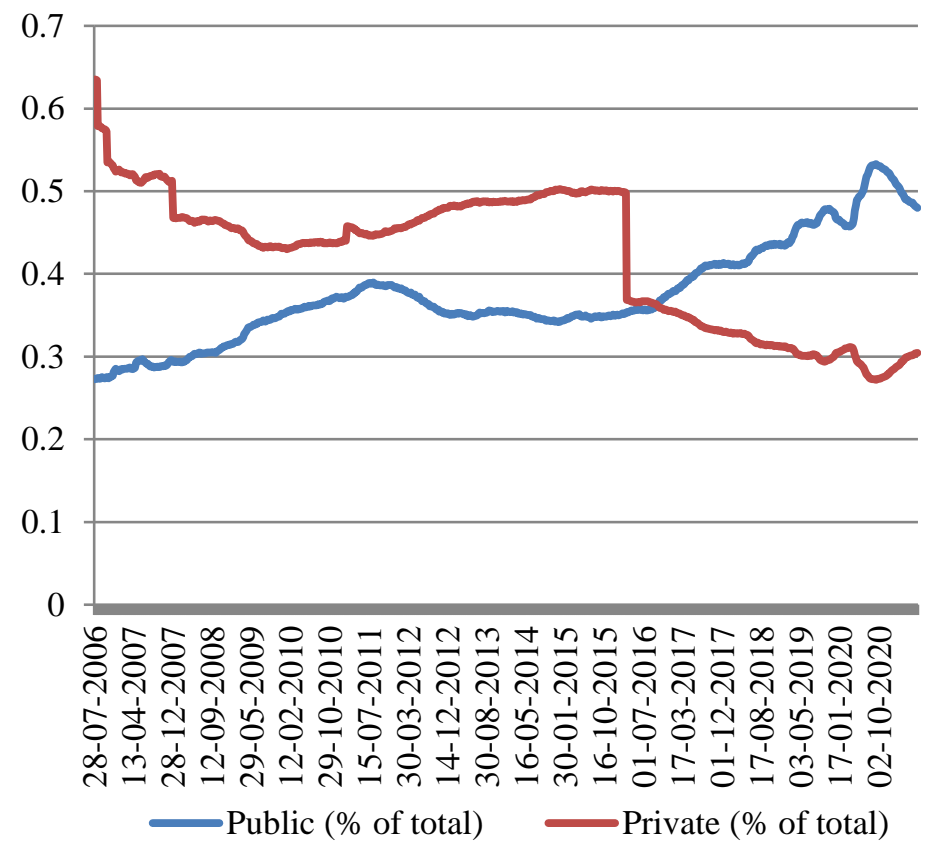

Figure 10. Share of consumer credits provided by the types of banks (2006-2021, weekly) Source: CBRTEVDS Data Central

Using the data of the 2003 Turkish Household Budget Survey, quite remarkable results were obtained as a result of investigating the socio-economic and demographic factors that determine the borrowing preferences of households (Özkoç and Üçdoğruk, 2008). For example, the percentage of households in the low income group is 54.35 percent, while the ratio is 35 percent for the low-spending group. In other words, although the income level is low, the expenditures of the households are not proportionate to income. There are two opposite explanations for this result: The first one is the desire of the households to maintain the standard of living that is considered 
luxurious for their income group, or the basic needs which are more than their earnings. Considering the conditions of our country and the starvation line over the years, this result most probably stems from necessity rather than arbitrariness. The segment that can survive without borrowing is unfortunately not even half of the society. Borrowing households are under a debt obligation, especially to banks and stores. From another perspective, Duman (2013) examined household indebtedness in terms of both its causes and consequences. Accordingly, it is stated that wage earners in urban areas become indebted because they have more difficulty in the housing market. Falling home ownership rates mean that household balance sheet dynamics worsen because tenants have to pay monthly rents that limit their consumption spending and debt service capacity if they are in debt burden. In terms of consequences, a decreasing rate of home ownership and declined nominal income growth and/or increased distressed borrowing will squeeze debtor households in their capacity to meet their debt repayments.

In recent years, the share of consumer loans provided by public banks in Turkey has increased more than the loans provided by private banks. Referring to Figure 10, while the share of private banks in total credits decreased, the share of public deposit banks in the total credit volume (of public, private and foreign banks), which was 35 percent in 2014, increased to 50 percent as of 2021. It would not be wrong to say that this situation is the result of a debt-led growth strategy that is dependent on the loans to be provided by public banks due to the stagnation in wages, as the financial fragility that is triggered by increasing household indebtedness could not be afforded by private banks.

When the borrowing is encouraged as a government policy, the consequences of this strategy should be carefully and seriously examined. According to a study conducted to examine the regional income inequality and convergence dynamics in Turkey's gross domestic product, income inequality has a cyclical character, tending to increase in economic expansion periods and decrease in recession periods (Y1ldırım and Öcal, 2006). Credit booms are associated with periods of economic expansion, rising equity and housing prices, real value increase and expansion of external deficits in the growth phase and the subsequent decline is followed by opposite dynamics (Mendoza and Terrones, 2008).

Other than the inequality indicators of labor income share or wages, income distribution measured by Gini coefficient and the ratio of top 10 percent to the bottom 10 percent are also presented in Figure 11. From 2010 onwards, both measures reveal that inequality has an increasing trend in Turkey. If we consider Figure 9 and Figure 11 together, it is possible to infer that household debt contributes to inequality by increasing the relative income share at the top of the distribution. The fact that the interest payments are used as a channel of indebtedness should not be neglected here. Wood (2020) similarly argues that since debtors transfer income to financial sector, household debt should be recognized as an important intermediary point between the income and wealth inequalities that contribute to the contrary social relations between wealthy and less wealthy households.

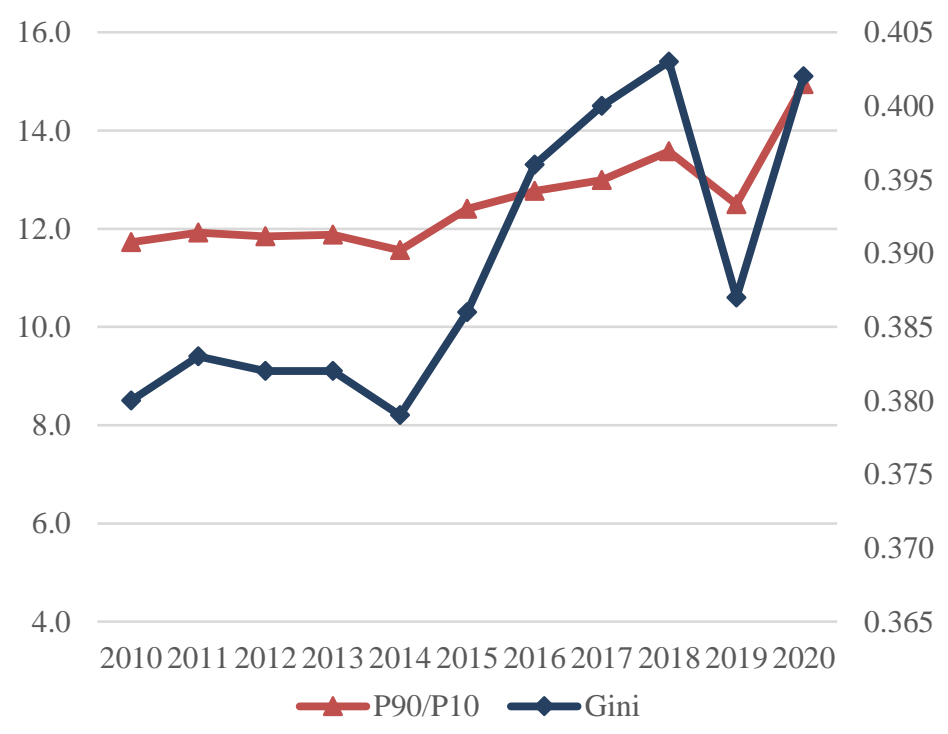

Figure 11. Gini coefficient and P90/P10 ratio by household disposable income (2010-2020)

Source: TurkSTAT

\section{Conclusion}

In the neoliberal era defined as the 1980s, profitability was aspired to be ensured through financial deregulation policies and financialization, and labor-capital conflict came to the fore again in this context. As a matter of fact, while these policies are remedies to capitalists' pursuit of profit, they have focused on maintaining this at the 
expense of wages and labor share of income, or deregulations in labor markets. However, since the sustainability of capital accumulation and profitability depends on the aggregate demand, higher profit expectations worked against the worker households. A way to maintain this mechanism has been the well-functioning of the credit system to stimulate aggregate demand. In today's financial system by which credits are substituting wages, the credit market should be considered from the perspective of both lenders and borrowers.

Within the framework of this understanding, demand is sustained by increasing amount of lending via financial institutions rather than with higher wages. The increase in household indebtedness, however, pushed the lowincome segment of the population to a high level of debt burden instead of benefiting them from the developments in the financial system. As a matter of fact, an increase in indebtedness in the presence of stagnant or lower wages would be able to maintain the required demand for a certain period of time, contributing to the existing inequality and debt burden which make sustainability of the system impossible. This is what was observed in the United States before the 2008/09 financial crisis.

The fact that similar relations between indicators were observed in the Turkish economy, particularly in the 2000 s, made it necessary to discuss the issue for working households in Turkey. As presented by the relevant data, indicators of income distribution like real wages, labor income share, Gini coefficient or top income ratio point to higher inequality among households in Turkey, while the indicators of credit supply and household indebtedness have been also increasing since the 2000s. What is needed to be declared here is that the decline in real wages is together with rising labor productivity. This situation has created a debt mechanism that convinces both the lenders and borrowers in terms of the sustainability of consumption. Indebtedness transfers income from workers to owners of capital through higher interest payments, in turn resulting in greater inequality. However, focusing on the factors that increase inequality here, trying to understand the roots of the matter, namely the stagnation/decrease in real wages and the decreasing share of labor over time, is necessary in order to permanently deal with this circle. This vicious circle based on household debt that we refer to is not sustainable and exacerbates the inequality in income distribution. Whether these relations create a vicious circle as we claimed here is still an open question which should be considered more broadly in further studies.

\section{References}

- Alvarez-Cuadrado \& Japaridze, 2017. "Trickle-down consumption, financial deregulation, inequality, and indebtedness", Journal of Economic Behavior \& Organization, 134, p. 1-26.

- Bahçe and Köse, 2016. "Financialisation/Borrowing Circle as a Solution to an Unpleasant Conundrum: Observations from the Mature Neoliberalism in Turkey", Research and Policy on Turkey, 1(1), p.63-74.

- Barba and Pivetti, 2009. "Rising household debt: Its causes and macroeconomic implications-a long-period analysis", Cambridge journal of economics, 33(1), p.113-137.

- Berisha and Meszaros, 2018. "Household debt, consumption, and income inequality", International Economic Journal, 32(2), p.161-176.

- Berisha, Meszaros, and Olson, 2018. "Income inequality, equities, household debt, and interest rates: Evidence from a century of data", Journal of International Money and Finance, 80, p.1-14.

- Bordo and Meissner, 2012. "Does inequality lead to a financial crisis", Journal of International Money and Finance, 31(8), p.2147-2161.

- $\quad$ CBRT, 2021. Consumer loans by deposit money banks, EVDS Data Central. (Accessed on 11 June 2021)

- CBRT, 2021. Household debt statistics, https://www.tcmb.gov.tr/wps/wcm/connect/tr/tcmb+tr/main+menu/yayinlar/raporlar/finansal+istikrar+rapor

$\mathrm{u} /$

- Charpe, Flaschel and Proaño, 2012. "Income distribution, credit rationing and households' debt", Metroeconomica, 63(3), p.458-492.

- De Vita and Luo, Y. 2021. "Financialization, household debt and income inequality: Empirical evidence", International Journal of Finance \& Economics, 26(2), p.1917-1937.

- dos Santos, 2009. "At the heart of the matter: household debt in contemporary banking and the international crisis", Ekonomiaz, 72(3), p.54-77.

- Duman, 2013. "Household debt in Turkey: The critical threshold for the next crisis", Paper for ECOMOD.

- Dünhaupt and Hein, 2019. "Financialization, distribution, and macroeconomic regimes before and after the crisis: a post-Keynesian view on Denmark, Estonia, and Latvia", Journal of Baltic Studies, 50, p.435-465.

- $\quad$ Eksi and Kirdar, 2015. Emek Gelirlerinin ve Eşitsizliğinin Türkiye İçin Bir Analizi: 2002-2011. Turkish Economic Association Discussion Paper 2015/2. 
- Elveren and Galbraith, 2009. "Pay inequality in Turkey in the neo-liberal era, 1980-2001", European Journal of Comparative Economics, 6(2), p.177-206.

- Filiztekin and Çelik, 2010. "Türkiye'de bölgesel gelir eşitsizliği (Regional income inequality in Turkey)", Megaron, 5, p.16-127.

- Giraud and Grasselli, 2019. "Household debt: The missing link between inequality and secular stagnation", Journal of Economic Behavior \& Organization.

- Güngen, 2021. Borçlandırma Siyaseti: Türkiye’de Finansal İçerilme. İletişim Yayınları, İstanbul.

- Harvey, 2015. Neoliberalizmin Kısa Tarihi. Sel Yayıncılık, İstanbul.

- ILO, 2019. The Global Labor Income Share and Distribution: Key Findings. Data Production and Anaysis Unit, ILO Department of Statistics.

- Karaçimen, 2015. Türkiye'de Finansallaşma: Borç Kıskacında Emek. Sosyal Araştırmalar Vakfı Yayınları, İstanbul.

- Kim, Lima, and Setterfield, 2019. "Political aspects of household finance: debt, wage bargaining, and macroeconomic (in) stability”, Journal of Post Keynesian Economics, 42, p.16-38.

- Klein, 2015. "Inequality and household debt: a panel cointegration analysis", Empirica, 42, p.391-412.

- Kumhof and Rancière, 2011. "Unequal= Indebted: Higher income inequality in developed countries is associated with higher domestic and foreign indebtedness", Finance \& Development, 48(003).

- Lapavitsas, 2017. Finansallaşma ve kapitalizmin krizi (Translated by T. Öncel). İstanbul: Yordam Kitap.

- Lapavitsas and Dos Santos, 2008. "Globalization and contemporary banking: on the impact of new technology", Contributions to Political Economy, 27, p.31-56.

- Lavoie, 2006. Introduction to post-Keynesian economics. Palgrave Macmillan, New York.

- Mendoza and Terrones, 2008. An anatomy of credit booms: evidence from macro aggregates and micro data (No. w14049). National Bureau of Economic Research.

- OECD, 2021. GDP per hour worked (indicator). doi: 10.1787/1439e590-en (Accessed on 30 May 2021)

- OECD, 2021. Household debt (indicator). doi: 10.1787/f03b6469-en (Accessed on 10 May 2021)

- Önder, 2009. "Küresel kriz ve Türkiye ekonomisi”, Muhasebe ve Finansman Dergisi, 42, p.12-25.

- Ö̈zkoç and Üçdoğruk, 2008. "Hanenin borçlanma tercihinin Nested Logit Model ile belirlenmesi", Iktisat Isletme ve Finans, 23(268), p.35-61.

- Palley, 2009. "The limits of Minsky's financial instability hypothesis as an explanation of the crisis" (No. 11/2009). IMK Working Paper.

- Pariboni and Tridico, 2019. "Labour share decline, financialisation and structural change", Cambridge Journal of Economics, 43(4), p.1073-1102.

- Perugini, Hölscher and Collie, 2016. "Inequality, credit and financial crises", Cambridge Journal of Economics, 40(1), p.227-257.

- Rajan, 2010. Fault Lines: How hidden fractures still threaten the world economy. Princeton University Press, New Jersey.

- Slater and Spencer, 2014. "Workplace relations, unemployment and finance-dominated capitalism", Review of Keynesian Economics, 2(2), p.134-146.

- Stockhammer, 2012. "Financialization, income distribution and the crisis", Investigación Económica, 71(279), p.39-70.

- Stockhammer, Onaran and Ederer, 2009. "Functional income distribution and aggregate demand in the Euro area", Cambridge journal of Economics, 33(1), p.139-159.

- Tridico, 2012. "Financial crisis and global imbalances: its labour market origins and the aftermath", Cambridge Journal of Economics, 36(1), p.17-42.

- TurkSTAT, 2021. Income inequality data. https://data.tuik.gov.tr/

- Van Treeck, 2014. "Did inequality cause the US financial crisis", Journal of Economic Surveys, 28(3), p.421448.

- WID, 2019. World Inequality Database. (Accessed on July 2019)

- Wisman, 2013. "Wage stagnation, rising inequality and the financial crisis of 2008", Cambridge Journal of Economics, 37(4), p.921-945. 
- Wood, 2020. "Can household debt influence income inequality? Evidence from Britain: 1966-2016”, The British Journal of Politics and International Relations, 22(1), p.24-46.

- World Bank, 2021. Domestic credits to private sector. https://databank.worldbank.org/source/worlddevelopment-indicators

- Yeldan, 2016. Küreselleşme Sürecinde Türkiye Ekonomisi: Bölüşüm, Birikim ve Büyüme. İletişim Yayınları, İstanbul.

- Yildırım and Öcal, 2006. "Income inequality and economic convergence in Turkey", Transition Studies Review, 13(3), p.559-568. 